\title{
Mff Media \\ Poltekkes Makassar \\ FORMULASI KRIM M/A DENGAN VARIASI KONSENTRASI EKSTRAK BUAH PEPAYA (Carica papaya L.) MENGGUNAKAN EMULGATOR ASAM STEARAT DAN TRIETANOLAMIN
}

\author{
Formulation Of M/A Cream With The Concentration Variation Of Papaya Extract (Carica papaya L.) \\ Using Stearic acid and Trietanolamin Emulgator
}

\author{
Srimuliani Arbie ${ }^{1}$, Nining Sugihartini ${ }^{2 *}$, Iis Wahyuningsih ${ }^{3}$ \\ Universitas Bina Mandiri, Gorontalo ${ }^{1}$ \\ Universitas Ahmad Dahlan, Yogyakarta ${ }^{2}$ \\ Universitas Ahmad Dahlan, Yogyakarta ${ }^{3}$
}

*Koresponden Email : nining.sugihartini@ pharm.uad.ac.id

DOI: https://doi.org/10.32382/mf.v16i1.1420

\begin{abstract}
Papaya fruit extract acts as a sunscreen and antityrosinase because it contains phenolic compounds such as flavonoids. The direct use of the extract on the skin is very impractical and therefore needs pharmaceutical preparation, specifically the cream. This study determines the effect of the ethanol extract concentration of papaya on the oil cream base in water and the physical properties of the preparation. Papaya fruit extracts were obtained by the maceration method using $70 \%$ ethanol and formulated as oiltype cream preparations. This involved a variation of extract concentration of $1 \%, 3 \%$, and $5 \%$ using a triethanolamine emulgator. The cream preparations were evaluated for physical properties, including determination of $\mathrm{pH}$, spreadability, adhesion, viscosity, and stability testing. The results showed that increasing the concentration of papaya extract affects physical properties, such as reducing the $\mathrm{pH}$ value $(\mathrm{p}<0.05)$, viscosity $(\mathrm{p}<0.05)$, and adhesion $(\mathrm{p}<0.05)$, as well as increasing the value of dispersion ( $\mathrm{p}$ $<0.05$ ). Physical stability of the papaya extract cream preparation did not occur at $1 \%$ and $3 \%$ extract concentrations. However, there was a separation at $3 \%$ extract concentration marked by creaming.
\end{abstract}

Keywords: Papaya fruit, Oil cream in water, Physical Properties

\section{ABSTRAK}

Ekstrak buah pepaya memiliki aktivitas sebagai tabir surya dan antitirosinase karena mengandung senyawa fenolik seperti flavonoid. Penggunaan ekstrak secara langsung di kulit sangat tidak praktis, untuk itu dipilih suatu sediaan farmasi yaitu sediaan krim. Tujuan penelitian ini adalah untuk mengetahui pengaruh konsentrasi ekstrak etanol daging buah pepaya dalam basis krim minyak dalam air terhadap sifat fisik sediaan.Ekstrak buah pepaya diperoleh dengan metode maserasi menggunakan etanol $70 \%$. Ekstrak kemudian diformulasikan dalam bentuk sediaan krim tipe minyak dalam air dengan variasi konsentrasi ekstrak 1\%,3\% dan 5\%. Sediaan krim ekstrak buah pepaya dievaluasi sifat fisik meliputi penetapan $\mathrm{pH}$, daya sebar, daya lekat, viskoisitas dan uji stabilitas. Hasil penelitian menunujukan bahwa peningkatan konsentrasi ekstrak buah pepaya dapat mempengaruhi sifat fisik yaitu : menurunkan nilai $\mathrm{pH}$ $(p<0,05)$, viskositas $(p<0,05)$, daya lekat $(p<0,05)$ dan dapat meningkatkan nilai daya sebar $(p<0,05)$. Stabilitas fisik pada sediaan krim ekstrak buah pepaya tidak terjadi pemisahan pada formula I dan II tetapi terjadi pemisahan pada formula III yang ditandai adanya creaming.

Kata Kunci: Buah pepaya, Krim, Sifat Fisik.

\section{PENDAHULUAN}

Paparan sinar matahari adalah faktor lingkungan yang paling berbahaya yang dapat mempengaruhi kulit seperti penuaan dini, kulit terbakar atau hiperpigmentasi dan yang paling bahaya adalah dapat menyebabkan kanker kulit. Radiasi UV memiliki spektrum luas mulai dari
40 hingga $400 \mathrm{~nm}$, yang terbagi menjadi 3 komponen yaitu UVA yang memiliki panjang gelombang tertinggi (320-400nm), UV B (290$320 \mathrm{~nm}$ ) dan UV C dengan panjang gelombang terpendek (220-290) (DeBuyset al, 2000). Agen photokemoprotektif mampu mencegah efek buruk dari radiasi ultraviolet pada kulit, yang 
disebabkan oleh paparan berlebihan dari radikal bebas (Saraf et al, 2012). Agen photokemoprotektif tersebut biasanya terdapat pada produk-produk kosmetik.

Kosmetik yang berada di pasaran untuk melindungi kulit dari sinar matahari dan mengurangi hiperpigmentasi biasanya menggunakan tabir surya dan produk pencerah. Akan tetapi produk tersebut masih menggunakan bahan-bahan sintetik yang memberikan efek merugikan seperti pada produk tabir surya avobenzone, octinoxate, oxybenzone (organik) dan zink oxide, Titanium dioxide (inorganik) yang dapat menimbulkan efek merugikan seperti adanya toksisitas yang berkaitan dengan anafilaksis (MD et al., 2013). Sama halnya dengan produk pencerah yang kebanyakan bahan sintetiknya seperti hidroquinone dan merkuri dapat bersifat karsinogenik (Masum et al, 2019). Dengan melihat adanya efek berbahaya yang ditimbulkan dari bahan-bahan sintetik maka dibutuhkan suatu pengembangan produk tabir surya dan produk pencerah dari sumber yang berbeda yaitu dari sumber alami. Salah satu tanaman yang dapat dijadikan sebagai sumber alami adalah buah pepaya.

Pepaya adalah sumber nutrisi yang tersedia sepanjang tahun, menjadi urutan ketiga sebagai antioksidan kuat mengandung vitamin $\mathrm{C}$, vitamin A dan vitamin E, mineral, magnesium, kalium, folat dan serat. Selain itu, mengandung metabolit sekunder yang berpotensi sebagai antioksidan seperti flavonoid, polifenol,alkaloid tannin (Addai et al, 2013). Menurut penelitian yang dilakukan oleh (Fajrin dan Tunjung, 2015)bahwa buah pepaya memiliki kandungan flavonoid $0,59 \% \mathrm{~b} / \mathrm{b}$. Penelitian lain juga menyebutkan bahwa ekstrak etanol daging buah pepaya memiliki kandungan flavonoid sebesar $66,3 \mu \mathrm{g} / \mathrm{mL}$ (Jinget al, 2019)

Melihat adanya potensi dari ekstrak buah pepaya maka diperlukan pengembangan bentuk sediaan yang cocok untuk digunakan pada kulit. Penggunaan ekstrak secara langsung di kulit sangat tidak praktis, untuk itu dipilih suatu sediaan farmasi yaitu sediaan krim. Pemilihan krim pada penelitian ini karena memiliki beberapa keuntungan diantaranya dapat digunakan untuk menghantarkan obat yang menunjukkan kelarutan dalam air yang rendah, dapat digunakan untuk mengurangi iritasi dengan memformulasikan sediaan dalam bentuk emulsi minyak dalam air (Jones, 2008). Menurut penelitian yang dilakukan oleh Rahmawati et al, 2010)bahwa krim dengan tipe minyak dalam air memiliki daya sebar daya proteksi yang sangat baik dibandingkan dengan tipe air dalam minyak. Selain itu krim minyak dalam air dapat memperlambat proses pengeringan kulit dan tidak mengiritasi sehingga cocok untuk penderita kulit sensitif (Murini, 2003).

Pada penelitian ini melakukan uji stabilitas fisik yang dilakukan untuk menjamin bahwa sediaan krim yang telah diformulasi memiliki kestabilan fisik yang baik yang ditandai dengan warna yang homogen, bau yang tidak tengik, viskositas, $\mathrm{pH}$ yang masuk dalam persyaratan krim dan tidak terjadinya pemisahan fase pada sediaan krim ini. Sediaan krim minyak dalam air menggunakan variasi konsentrasi ekstrak etanol $70 \%$ sebesar $1 \%$, 3\% dan $5 \%$. Alasan penggunaan konsentrasi ini diambil dari penelitian sebelumnya dimana dengan konsetrasi $5 \%$ ekstrak kental buah pepaya dapat melindungi kulit dari sinar ultraviolet dengan nilai SPF sebesar 30 (Khomaria, 2018). Tujuan dari penelitian ini yaitu untuk melihat adanya pengaruh konsentrasi ekstrak terhadap stabilitas fisik sediaan.

\section{METODE}

Desain penelitian ini termasuk dalam penelitian eksperimental dengan memvariasikan estrak etanol daging buah papaya $1 \%, 3 \%$ dan $5 \%$ yang dibuat dalam bentuk sediaan krim. Tempat penelitian dilaksanan di laboratorium Universitas Ahmad Dahlan pada bulan AgustusNovember 2019.

\begin{abstract}
Alat Dan Bahan
Alat yang digunakan dalam penelitian ini adalah $\mathrm{pH}$ meter (Ohaus), pipet volume (Iwaki), timbangan analitik (Ohaus), rotary evaporatory, viskometer (Rheosys), waterbath (Memmert). Bahan yang digunakan daam penelitian ini yaitu daging buah pepaya California mengkal usia 3-4 bulanyang diambil dari Perkebunan Pepaya Pundong, Yogyakarta, etanol $70 \%$ (Merck), Bahan penyusun krim disesuaikan dengan derajat farmasetik : air suling, asam stearat, butil hydroxyl toulene, glyserin, parafin cair, setil alkohol, TEA.
\end{abstract}

\section{Penyiapan Ekstrak}

Serbuk sampel yang telah ditimbang direndam dalam pelarut etanol $70 \%$ dengan rasio 1:40 selama 72 jam pada suhu kamar. Setelah itu difiltrasi dengan kertas saring dan pompa vakum. 
Maserat yang diperoleh diuapkan mengguanakan rotary evaporator pada suhu $70^{\circ} \mathrm{C}$ sampai terbentuk ekstrak kental.

\section{Formula Krim Ekstrak Buah Pepaya}

Formulasi sediaan krim minyak dalam air dapat dilihat pada tabel I yang dimodifikasi dari penelitian(Suryatiet al, 2015).

Tabel I. Formula Krim Minyak dalam Air dengan Konsentrasi Ekstrak Buah Pepaya

\begin{tabular}{|c|c|c|c|c|}
\hline \multirow[t]{2}{*}{ Nama Bahan } & \multicolumn{4}{|c|}{ Formulasi krim (\%) } \\
\hline & F0 & FI & FII & FIII \\
\hline $\begin{array}{c}\text { Ekstrak buah } \\
\text { pepaya }\end{array}$ & 0 & 1 & 3 & 5 \\
\hline Parafin Cair & 10 & 10 & 10 & 10 \\
\hline Setil alkohol & 1,5 & 1,5 & 1,5 & 1,5 \\
\hline Asam stearat & 5 & 5 & 5 & 5 \\
\hline Gliserin & 2 & 2 & 2 & 2 \\
\hline TEA & 2 & 2 & 2 & 2 \\
\hline BHT & 0,02 & 0,02 & 0,02 & 0,02 \\
\hline Propil Paraben & 0,05 & 0,05 & 0,05 & 0,05 \\
\hline Metil Paraben & 0,1 & 0,1 & 0,1 & 0,1 \\
\hline Aquades ad & 100 & 100 & 100 & 100 \\
\hline $\begin{array}{l}\text { Ket : F0 (Basis krim } \\
\text { dengan kandungan e } \\
\text { kandungan ekstrak } 3 \\
\text { kandungan ekstrak } 5\end{array}$ & $\begin{array}{l}\text { yak dal } \\
\text { k } 1 \% \text {, } \\
\text { FIII (F }\end{array}$ & $\begin{array}{l}\text { air, FI } \\
\text { (Form } \\
\text { ula kri }\end{array}$ & $\begin{array}{l}\text { ormul } \\
\text { krim } \\
\text { dengan }\end{array}$ & rim \\
\hline
\end{tabular}

\section{PEMBUATAN SEDIAAN KRIM}

Fase minyak dibuat dengan melebur asam stearat, setil alkohol,dan parafin cair dalam cawan porselin diatas waterbath dengan suhu $80^{\circ} \mathrm{C}$. Setelah basis minyak melebur, ditambahkan propil paraben dan BHT kedalamnya serta diaduk sampai larut dan homogen. Untuk fase air dilakukan dengan memanaskan aquades setelah itu dimasukkan metil paraben, setelah metil paraben larut dalam air kemudian dimasukan TEA dan gliserin, lalu diaduk sampai homogen. Selanjutnya campuran ini dihangatkan sampai suhu $80^{\circ} \mathrm{C}$. Fase minyak dimasukkan ke dalam fase air kemudian dihomogenkan dengan homogenizer. Kemudian ditambahkan dengan ekstrak buah pepaya sedikit demi sedikit hingga tercampur homogen.

\section{Evaluasi Sediaan Fisik Penetapan pH}

Sediaan krim diuji menggunakan $\mathrm{pH}$ meter dengan cara dicelupkan dalam sampel, Nilai $\mathrm{pH}$ yang ditunjukkan dicatat dan direplikasi sebanyak 3 kali (Pratimasariet al, 2015) Penetapan viskositas
Sediaanditentukan viskositasnya dengan viskosimeter Rheosys Merlin VR dengan menggunakan spindel $25 \mathrm{~mm}$ concentric cylinders. Krim ditempatkan ke dalam plate dan cone diposisikan untuk memulai pengukuran. Parameter pengukuran diatur agar persis sama sehingga semua formula mendapatkan perlakuan yang sama kemudian dijalankan komputer dengan aplikasi Rheosys Micra. Data yang didapatkan akan dihitung regresi untuk mengetahui sifat alir, setelah sifat alir diketahui maka dapat ditentukan nilai viskositasnya (Edityaningrum et al., 2018)

\section{Uji Daya Sebar}

Lima ratus mg sediaan diletakkan di atas kaca bulat berskala kemudian ditutup dengan menggunakan kaca bulat yang telah ditimbang dan diketahui bobotnya selama 5 menit serta dicatat diameter penyebarannya. Kemudian ditambahkan beban seberat $50 \mathrm{~g}$ selama 1 menit, dicatat diameter penyebarannya.Kemudian dilanjutkan dengan beban seberat $100 \mathrm{~g}$, catat diameter penyebarannya. Replikasi dilakukan 3 kali. Dilakukan uji yang sama untuk formula lain (Rahmawatiet al, 2010)

\section{Uji Daya Lekat}

Lima ratus mg diletakan di objek glass dengan luas tertentu, kemudian ditutup objek gelas lain, ditekan dengan menggunakan beban seberat $1 \mathrm{Kg}$ selama 5 menit. Objek gelas dipasang pada alat uji, dilepas dengan beban seberat 80 gram dan waktu yang diperlukan untuk memisahkan kedua objek tersebut. Replikasi dilakukan 3 kali. Uji yang sama dilakukan pada formula yang lain (Haque dan Sugihartini, 2005)

\section{Uji Stabilitas Fisik}

Krim disentrifugasi dengan kecepatan 3750 rpm selama 5 jam karena hasilnya ekivalen dengan efek gravitasi selama 1 tahun. Setelah disentrifugasi, diamati apakah terjadi pemisahan fase atau tidak (Rieger, 2000)

HASIL

Hasil penelitian dapat dilihat dibawah ini

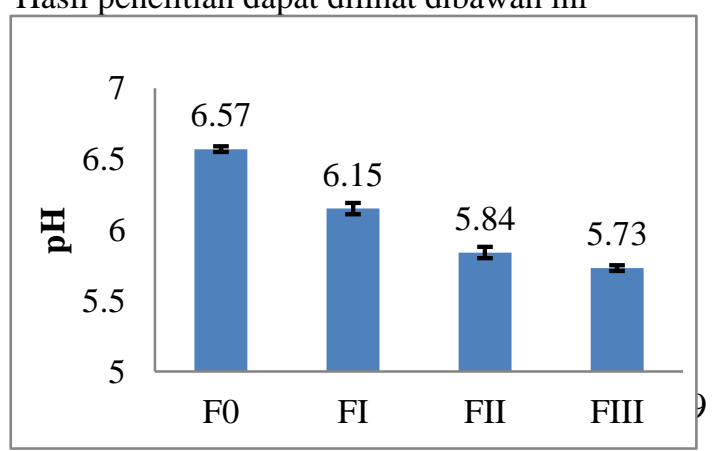


Gambar 1. Grafik Hubungan Antara Konsentrasi 0\% (Formula I), 1\% (Formula II), 3\% (Formula III) ekstrak etanol buah pepaya pada krim minyak dalam air dengan $\mathrm{pH}$.

Berdasarkan grafik ini dengan setiap penambahan ekstrak dapat menyebabkan penurunan $\mathrm{pH}$

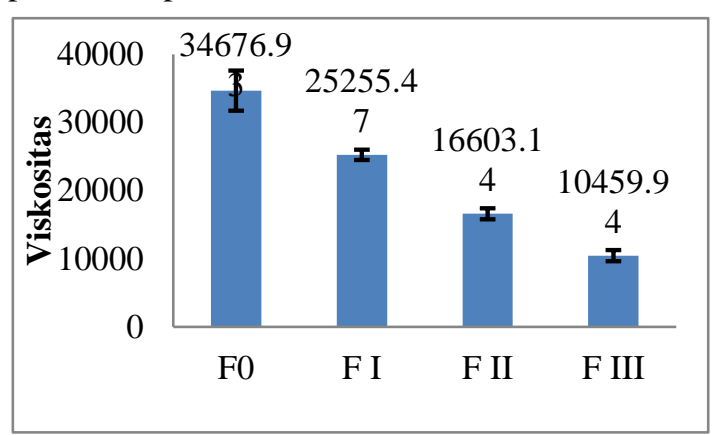

Gambar 2. Grafik Hubungan Antara Konsentrasi 0\% (Formula I), 1\% (Formula II), 3\% (Formula III) ekstrak etanol buah pepaya pada krim minyak dalam air dengan viskositas.

Berdasarkan grafik ini dengan setiap penambahan ekstrak dapat menyebabkan penurunan viskositas

Tabel 2. Hasil tipe alir sedian krim minyak dalam air

\begin{tabular}{ccccc}
\hline No & Formula & R & R log & Aliran \\
\hline 1 & F0 & 0,949 & 0,979 & Pseudoplastis \\
2 & F I & 0,914 & 0,968 & Pseudoplastis \\
3 & F II & 0,946 & 0,978 & Pseudoplastis \\
4 & F III & 0,925 & 0,958 & Pseudoplastis \\
\hline
\end{tabular}

Ket : F0 (Basis krim minyak dalam air, FI (Formula krim dengan kandungan ekstrak 1\%, FII (Formula krim dengan kandungan ekstrak 3\%), FIII (Formula krim dengan kandungan ekstrak 5\%.

Berdasarkan tabel ini terlihat bahwa keempat formula memiliki aliran pseudoplastis.

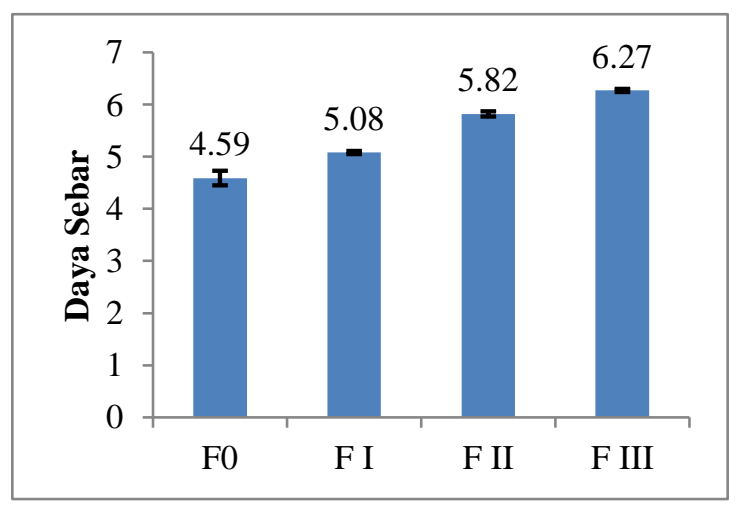

Gambar 4. Grafik Hubungan Antara Konsentrasi 0\% (Formula I), 1\% (Formula II), 3\% (Formula III) ekstrak etanol buah pepaya pada krim minyak dalam air dengan daya sebar.

Berdasarkan grafik ini dengan setiap penambahan ekstrak dapat menyebabkan kenaikan daya sebar.

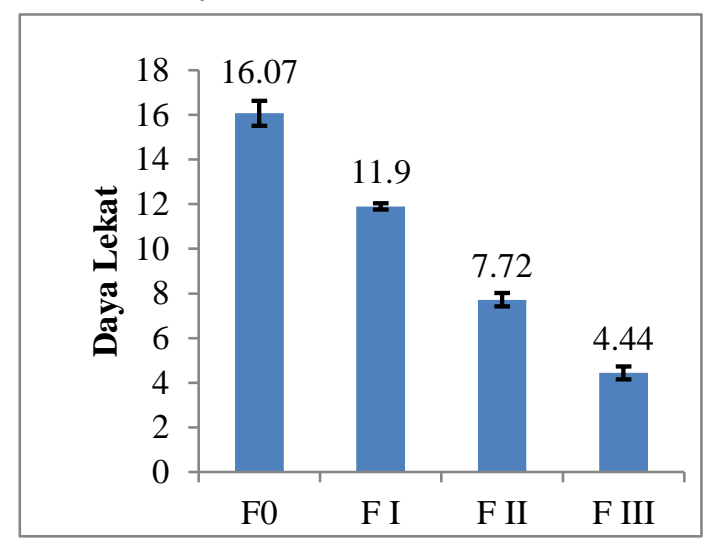

Gambar 5. Grafik Hubungan Antara Konsentrasi 0\% (Formula I), 1\% (Formula II), 3\% (Formula III) ekstrak etanol buah pepaya pada krim minyak dalam air dengan daya lekat.

Berdasarkan grafik ini dengan setiap penambahan ekstrak dapat menyebabkan penurunan daya lekat.

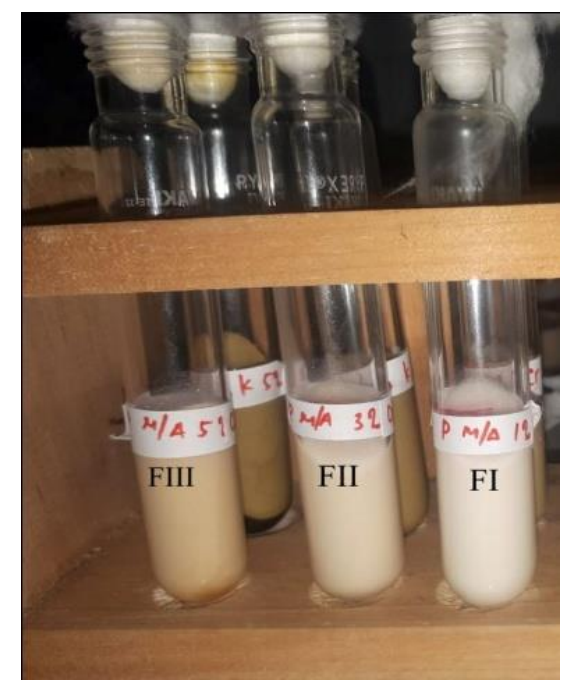

Gambar 6. Uji Sentrifugasi 

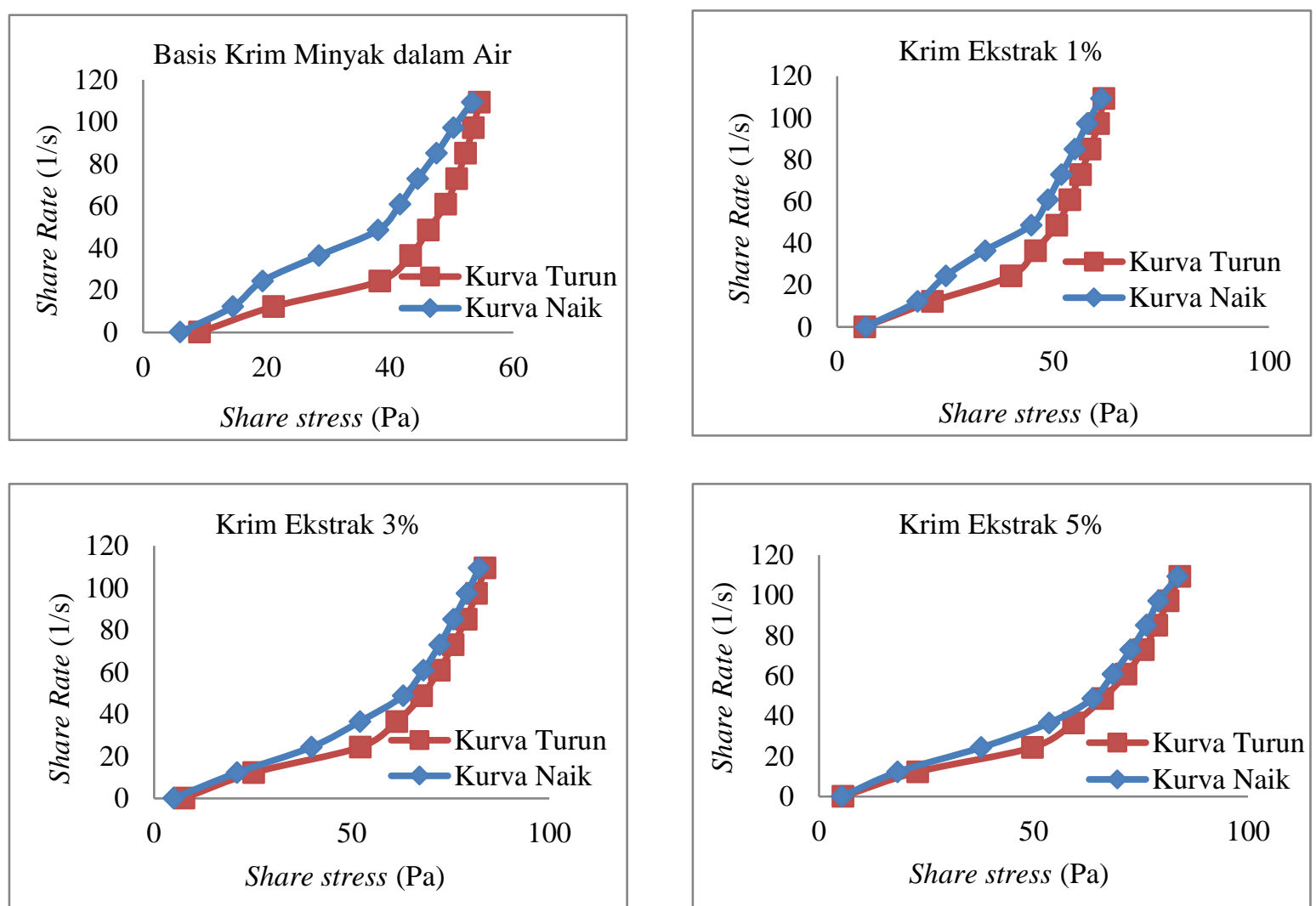

Gambar 3. Grafik rheogram hubungan antara Shearing rate (SS) vs Shearing Stress krim ekstrak buah papaya. Berdasarkan grafiik ini keempat formula memiliki aliran pseudoplastis.

\section{PEMBAHASAN}

Ekstrak buah pepaya akan diformulasikan dalam bentuk sediaan krim tipe minyak dalam air. Untuk melihat kualitas fisik yang dihasilkan dari sediaan krim maka dilakukan pengujian stabilitas fisik yang meliputi penetapan $\mathrm{pH}$, uji daya sebar, uji daya lekat, penetapan viskositas dan uji sentrifugasi.

Penetapan $\mathrm{pH}$ bertujuan untuk melihat tingkat keasamaan yang dihasilkan dari sediaan untukmenjamin bahwa sediaan tidak akan menimbulkan iritasi pada kulit(Mappa et al, 2013). Suatu sediaan sangat diharapkan memiliki nilai rentang $\mathrm{pH}$ 4,5-6,5 karena jika suatu sediaan terlalu asam maka dapat mengiritasi kulit dan jika terlalu basa dapat membuat kulit kering bersisik (Swastikaet $a l$, 2013). Hasil pengujian $\mathrm{pH}$ pada krim M/A ekstrak etanol buah pepaya berada diantara $\mathrm{pH} 5-6$, dimana $\mathrm{pH}$ tertinggi ada pada formula tanpa basis hal ini dikarenakan pada ekstrak etanol buah pepaya mengandung senyawa flavonoid yang merupakan golongan terbesar dari senyawa fenol yang bersifat agak asam (Alvianti et al., 20/18). Sehingga semakin banyak ekstrak yang ditambahkan pada sediaan krim minyak dalam air maka semakin rendah $\mathrm{pH}$ yang dihasilkan.

Hasil uji statistik menunjukan ada perbedaan signifikan antara keempat kelompok formula $(p<0,05)$. Hal ini berkesesuaian dengan hasil penelitian formulasi sediaan krim pelembab ekstrak air buah pepaya (Ningsihet al, 2019). Hasil penelitian tersebut menunjukan bahwa peningkatan konsentrasi ekstrak air buah pepaya dapat menurunkan nilai $\mathrm{pH}$. Hasil penetapan $\mathrm{pH}$ dapat dilihat pada gambar 1

Viskositas bertujuan untuk mengetahui tingkat kekentalan dari sediaan. Viskositas merupakan suatu pernyataan tahanan dari suatu cairan untuk mengalir. Sediaan krim pada umumnya memiliki tipe aliran non-newtonian. Viskositas krim yang baik berkisar antara 2000-50000 cps (Martin et $a l, 2012$ ). Hasil viskositas yang didapat bahwa setiap 
penambahan ekstrak buah pepaya dapat menurunkan viskositas dari sediaan. Tetapi hasil yang didapatkan masih masuk range dari viskositas yang baik untuk sediaan krim. Hasil viskositas dapat dilihat pada gambar 2.

Pada tabel 2 menjelaskan bahwa hasil perhitungan antara hubungan SS vs SR menunjukan bahwa dari keempat formula memiliki sifat alir pseudoplastis karena nilai koefisien korelasi (r) hubungan antara log SS vs SR lebih besar dibandingkan dengan SS vs SR dan nilai Slope (B) lebih dari 1.

Reogram yang ditunjukan pada gambar 3menunjukan aliranpseudoplastis. Karaktersiktik pseudoplastis dapat mengalir secara langsung terhadap peningkatan gaya geser yang akan diberikan. Sehingga adanya peningkatan gaya geser ini akan membuat sediaan krim akan mengalami kerusakan struktur internal maka krim dapat tersebar dengan mudah pada kulit.pada saat diaplikasikan. Ketika gaya geser diturunkan maka struktur krim akan terbentuk kembali dan krim akan dapat menempel pada kulit (Banarjee dan Thiagrajan, 2017)

Hasil uji statistik menunjukan ada perbedaan signifikan antara keempat kelompok formula $(\mathrm{P}<0,05)$, yang berarti setiap penambahan konsentrasi ekstrak etanol daging buah pepaya menurunkan viskositas krim secara signifikan. Penelitian ini berkesesuaian dengan penelitian optimasi sediaan krim ekstrak etanol daun muda papaya sebagai antioksidan (Himaniarwaty, 2019) dimana hasil penelitian tersebut menunjukan peningkatan konsentrasi ekstrak dapat menurunkan nila viskositas sediaan.

Daya sebar bertujuan untuk mengetahui sediaan krim dapat menyebar dengan baik pada kulit(Arisanty dan Anita, 2018). Penyebaran sediaan krim pada saat digunakan berkaitan erat dengan daya sebar. Semakin tinggi daya sebar maka semakin luas daya kontak krim dengan permukaan kulit, sehingga zat aktif dapat terdistribusi dengan baik(Swastika et al, 2013). Daya sebar yang baik memiliki nilai yaitu sekitar 5-7 cm (Uleanet al, 2012).Dari hasil uji daya sebar didapatkan bahwa keempat formula memenuhi syarat uji daya sebar, pada F III didapatkan nilai daya sebar yang paling tinggi.

Hasil uji statistik menunjukan ada perbedaan signifikan antara keempat kelompok formula $(\mathrm{p}<0,05)$. Hal ini berkesesuaian dengan penelitian (Haque dan Sugihartini, 2005). Hasil penelitian mengatakan bahwa semakin tinggi konsentrasi ekstrak maka semakin tinggi pula daya sebarnya yang dilihat dari viskositas. Nilai viskositas dari krim yang didapatkan berbanding terbalik dengan daya sebar. Semakin tinggi jumlah ekstrak yang ditambahkan maka semakin rendah nilai viskositas, semakin rendah nilai viskositas maka dapat meningkatkan nilai daya sebar. Hasil uji daya sebar dapat dilihat pada gambar 4 .

Daya lekat bertujuan untuk mengetahui berapa lama sediaan krim dapat bertahan pada kulit. Daya lekat krim berhubungan dengan seberapa lama suatu sediaan krim dapat bertahan lama dikulit. krim yang baik dapat menjamin waktu kontak dengan kulit sehingga dapat mencapai efek yang maksimal, akan tetapi krim juga tidak boleh terlalu lengket pada saat digunakan karena melihat dari segi kenyamanan pada saat digunakan. Daya lekat dapat mempengaruhi efektivitas zat aktif dalam suatu sediaan krim, dimana semakin lama daya lekatnya maka aktivitas yang akan dimaksudkan juga akan bertahan lebih lama (Swastika et al, 2013). Persyaratan daya lekat untuk sediaan topikal yaitu lebih dari 4 detik (Mukhlishah et al, 2016). Pada hasil uji daya lekat dapat dilihat bahwa keempat formula memenuhi syarat karena hasil yang didapatkan berkisar antara 4,44-16,07 detik.

Hasil uji statistik pada uji daya lekat ini diuji menggunakan anova dimana hasil yang ditunjukan adalah normal dan homogen $(\mathrm{p}>0,05)$. Setelah itu dilanjutkan ke uji LSD untuk melihat adanya perbedaan kelompok konsentrasi ekstrak buah pepaya. Hasil uji LSD menunjukan ada perbedaan signifikan antara keempat kelompok formula $(\mathrm{p}<0,05)$. Hal ini berkesesuaian dengan penelitian (Haque dan Sugihartini, 2005). Hasil penelitian mengatakan bahwa semakin tinggi konsentrasi ekstrak maka semakin rendah pula daya lekatnya, hal ini berhubungan dengan viskositas yang semakin rendah akan menyebabkan daya lekatnya pun semakin rendah dan begitu juga sebaliknya. Hasil uji daya lekat dapat dilihat pada gambar $\mathbf{5}$.

Uji sentrifugasi dilakukan untuk melihat ketahanan dan kestabilan sediaan krim yang berhubungan dengan shelf life sediaan yang sama besarnya dengan pengaruh gravitasi terhadap penyimpanan krim selama setahun.Berdasarkan hasil uji sentrifugasi dengan kecepatan $3750 \mathrm{rpm}$ selama 5 jam menunjukan bahwa FIII terlihat sedikit pemisahan yang ditandai dengan adanya perbedaan warna pada bagian dasar tabung sentrifugasi, hal ini dinamakan creaming. Akan tetapi FI dan FII terlihat stabil karena tidak mengalami adanya pemisahan fase. Hal ini dikarenakan formula I dan formula II memiliki kekentalan yang cukup tinggi. Viskositas yang tinggi akan membuat laju sedimentasi sediaan semakin lambat sehingga pembentukan creaming tidak akan terjadi. Creaming adalah terbentuknya lapisan-lapisan dengan konsentrasi yang berbedabeda pada emulsi. Hal ini dipengaruhi oleh gaya gravitasi dimana partikel yang memiliki kerapatan 
yang tinggi akan membentuk suatu lapisan pada bagian bawah sediaan dan partikel yang memiliki kerapatan rendah akan terdorong kepermukaan(Pujiastutiet al., 2019)

Pemisahan yang terjadi pada FIII juga dapat terjadi karena ikatan antara minyak dan air menjadi tidak stabil disebabkan karena adanya gaya sentrifugasi yang menyebabkan partikel-partikel akan berpisah sesuai dengan berat jenisnya. Berat jenis berbanding lurus dengan laju pengendapan, berat jenis fase air lebih besar dibandingkan dengan fase minyak sehingga sedimentasinya menjadi kecil dan akan terbentuk creaming(Anwar, 2012). Penelitian lain menngatakan bahwa hubungan viskositas sediaan dan pemisahan dapat dilihat dari hukum stokes, dimana viskositas berbanding terbalik dengan kecepatan pemisahan. Tinggi rendahnya viskositas ditentukan dengan kadar dari ekstrak, semakin tinggi viskositas sediaan maka kecepatan pemisahan krim semakin lambat ( Shovyana, 2013).

\section{KESIMPULAN}

Variasi konsentrasi ekstrak buah pepaya dalam sediaan krim minyak dalam air memiliki pengaruh pada penurunan nilai $\mathrm{pH}$ $(\mathrm{p}<0,05)$, viskositas $(\mathrm{p}<0,05)$, daya lekat $(\mathrm{p}<0,05)$, serta peningkatan nilai daya sebar $(\mathrm{p}<0,05)$. Stabilitas fisik pada sediaan krim ekstrak buah pepaya tidak terjadi pemisahan pada formula I dan II tetapi terjadi pemisahan pada formula III yang ditandai adanya creaming.

\section{DAFTAR PUSTAKA}

Addai, Z., Abdullah, A. and Muthalib, S. (2013) 'Effect of Extraction Solven on the Phenolic Content and Antioxidant Properties of Two Pepaya California', J Med Plant Research, 7(47), 3353-3359.

Alvianti, N. et al. (2018) 'Formulasi Sediaan Krim Anti Jerawat Ekstrak Etanol Daun Kersen (Muntingia calabura L.) Jurnal Dunia Farmasi3(1), 24-31.

Anwar, E. (2012) Eksipien dalam Sediaan Farmasi Karakterisasi dan Aplikasi. Jakarta: Dian Rakyat.

Arisanty, A. and Anita, A. (2018) 'Uji Mutu Fisik Sediaan Krim Ekstrak Etanol Buah Belimbing Wuluh (Averrhoa bilimbi L.) Dengan Variasi Konsentrasi Na. Lauril Sulfat', Media Farmasi, 14(1), 22.

Banarjee, K. and Thiagrajan, P. (2017) 'Formulation Optimisazion, Rheological Characterization and Suitability Studies of Polyglucoside-based
Azadirachta indica A. Juss Emollient Cream as a Dermal Base for Sun Protection Aplication', Indian Journal of Pharmaceutical Sciences, 79(6), 914-922.

DeBuys, H., Levy, S. and Murray, J. (2000) 'Modern approaches to photoprotection', Dermatol Clin, 18(4), 557-590.

Dewi, Rahmawati. Anita, Sukmawati. dan Peni, I. (2010) 'Formulasi Krim Minyak Atsiri Rimpang Temu Giring (Curcuma heyneana Val \& Zijp ): Uji Sifat Fisik dan Daya Antijamur, Majalah Obat Tradisional, 15(2), 56-63.

Edityaningrum C.A, Kintoko, Zulien F, and Widiyastuti L. (2018). "Optimization of Water Fraction Gel Formula of Binahong Leaf (Anredera Cordifolia (Ten.) Steen) With Gelling Agent of Sodium Alginate and Carboxymethyl Chitosan Combination." Majalah Obat Tradisional 23 (3): 97.

Fajrin, A. and Tunjung, W. A. S. (2015) 'The Flavonoids Content In Leaves and Fruits of Papaya (Carica papaya L.) Var. California and Var. Gandul', KnE Life Sciences, 2(1), 154.

Haque, A. and Sugihartini, N. (2005) 'Evaluasi Iritasi dan Uji Sifat Fisik pada Sediaan Krim M/A Minyak Atsiri Bunga Cengkeh dengan Berbagai Variasi Konsentrasi', Jurnal Farmasi Indonesia, 12(2), 131-139.

Hilmaniarwati, Lolok, N., Nasir, N, H., Chulaifah, D. (2019) ' Optimasi Sediaan Krim dari Ekstrak Etanol Daun Muda pepaya (Carica papaya L.) Sebagai Antioksida. Jurnal Mandala Pharmacon Indonesia 5(1), 1-9.

Jing, Seow Lay., Yen, Khor Poh., Dash, Gouri Kumar, (2019), In Vitro Antioxidant and Photoprotective Activities of Carica Papaya Fruits, Asian Journal of Pharmaceutical and Clinical Research, 12(4), 308-310.

Jones, D. (2008) Pharmaceutical Dosage From and Design. London: Pharmaceutical Press.

Khomaria, Y. (2018). 'Kandungan Total Fenolik Dan Flavonoid Serta Potensinya Sebagai Antiaging Dan Penghambat Tirosinase Ekstrak Etanol Buah Pepaya Dengan Variasi Konsentrasi Pelarut.'Tesis. Universitas Ahmad Dahlan.,jji

Mappa, T., Edi, J. and Kojong, M. (2013) 'Formulasi Gel Ekstrak Daun Sasaladahan (Pperomia pellucida L.) dan Uji Efektivitasnya Terhadap Luka Bakar pada Kelinci', Jurnal Ilmiah Farmasi, 2(20), 49-56. 
Martin, A., Awabrick, J. and Cmmarat, A. (2012) Farmasi Fisik Dasar-Dasar Farmasi Fisik dalam Ilmu Farmasetik. Jakarta: Universitas Indonesia.

Masum, M., Yamaguchi, K. and Mitsunaga, T. (2019) 'Tyrosinase Inhibitors from Natural and Syntetic Sources as Skin-Lightening Agents', Reviews in Agricultural Sciences, 7, 41-58.

MD, M.S. Latha., MD, Jacintha Martis., MD, Sudhakar Bangera., Varughese, Sunoj., MD, Shobha V., MD, Binny Krishnankutty., Rao, Prabhakar Rao., Shinde, Rutuja Sham., BDS, Shantala Bellary., MBBS, B.R. Naveen Kumar, (2013), Suncreening Agents. The Journal of Clinical and Aesthetic Dermatology, 6(1), 1626.

Mukhlishah, N. R. izzatul, Sugihartini, N. and Yuwono, T. (2016) 'Daya Iritasi dan sifat fisik sediaan salep minyak atsiri bunga cengkeh (syzigium aromaticum) pada basis hidrokarbon', Majalah Farmaseutik, 12(1), 372-376.

Ningsih Sri Kadek, U., Lanawati, F. and Wijaya, S. (2019) 'Formulasi Sediaan Krim Pelembab Ekstrak Air Buah Pepaya ( Carica Papaya L .) Fakultas Farmasi, Universitas Katolik Widya Mandala Surabaya, Surabaya, Indonesia, 6(1).

Pratimasari, D., Sugihartini, N. and Yuwono, T. (2015) 'Evaluasi Sifat Fisik Dan Uji Iritasi Sediaan Salep Minyak Atsiri Bunga Cengkeh Dalam Basis Larut Air', Jurnal Ilmiah Farmasi, 11(1), 9-15.

Pujiastuti, Anasthasia., Kristiani, Monica, (2019), Formulasi dan uji stabilitas mekanik hand and body lotion sari buah tomat (Licopercison esculentum Mill) sebagai antioksidan, Jurnal Farmasi Indonesia, 16(1), 42-55.

Rieger, M. (2000) Harry's Cosmeticology. 8th edn. Newyork: Chemical Publishing Co Inc.

Saraf, S., Chhabra, S. . and Kaur, C. . (2012) 'Development of photochemoprotective herbs containing cosmetics formulations for improving skin properties', Journal of cosmetic science, 63, pp. 119-131.

Shovyana, H. H., Zaulkarnain K. ( 2013). ' Stabilitas Fisik dan Aktivitas Krim W/O Etanol buah mahkota dewa (Phaleria macrocarph (scheff) Beorl) Sebagai Tabir Surya'. Trad. Med. 18(2), 109-117

Suryati, Henry, L. and Dachriyanus (2015) 'Formulaation of Sunscreen Cream of Germanicol cinnamate from the Leaves of Tabat Barito (Ficus deltiodes Jack) and assay of it's Sun Protection Factor', International Journal of Pharmaceutical Sciences Review and Research, 104-107.

Swastika, A., Mufrod and Purwanto (2013) 'Aktivitas Antioksidan dan Krim Ekstrak Sari Tomat (Solanum copercisum L.)', Trad. Med. Journal, 18(3), 132-140.

Tri Murini (2003) 'Obat Jerawat Topical dan Bentuk Sediaannya yang Beredar di Indonesia', Jurnal Kedokteran Yarsi, 11(2).

Ulean, S., Banne, Y. and Suatan, R. (2012) 'Pembuatan Salep Anti Jerawat dari Ekstrak Rimpang Temulawak (Curcuma xanthorriza Roxb)', Jurnal Ilmiah Farmasi, 3(2), 45-49. 